\title{
FUNKCE SLOŽENÝCH SUBSTANCÍ V RÁMCI LEIBNIZOVY METAFYZIKY
}

\author{
Kateřina Lochmanová
}

\section{Úvod}

Za základní jednotky Leibnizovy metafyziky bývají obvykle považovány jednoduché substance zvané duše či monády. ${ }^{1} \mathrm{~V}$ předkládaném textu však poukážeme na to, že monádám, dokonce ještě v rámci Leibnizových pozdních spisů, silně konkuroval jiný typ substancí, totiž substance složené. ${ }^{2}$ Na místo monád by se tedy v souvislosti se základními jednotkami Leibnizovy metafyziky slušelo užívat spíše obecnějšího pojmu, totiž substance, nebot' monáda samotná ve skutečnosti představuje pouze jeden ze dvou dílčích typů substance jako takové. ${ }^{3}$ Dokladem této teze

1 Jak upozorňuje N. Fenton, ,dominantní hodnocení z Leibnize učinilo především obhájce monád." N. Fenton, A New Interpretation of Leibniz’s Philosophy. With Emphasis on His Theory of Space, Dallas 1979, str. 174. Takové hodnocení nabízí např. N. Jolley, podle něhož lze jen stěží pochybovat, že Leibniz byl v rámci svých pozdních spisů idealistou, který tvrdil, že jedinými substancemi jsou duše, jež ztotožňoval s jednoduchými substancemi a jimž přezdíval monády. Taková koncepce je ovšem dle autora naprosto neslučitelná s možností, že by Leibniz kromě duší uznával rovněž existenci fyzikálních těles. Viz N. Jolley, Leibniz and Phenomenalism, in: Studia leibnitiana, Supplementa, 18, 1986, str. 38-51, zejm. str. 40. Jolley upozorňuje na následující pasáže: G. W. Leibniz, Leibniz an Arnauld, in: týž, Die philosophischen Schriften, I-VII, vyd. B. Gerhardt (= GP), Berlin 1875-1890, II, str. 270; týž, Leibniz an des Bosses [26 Maji 1712], in: GP II, str. 444; týž, Conséquences métaphysiques, in: týž, Opuscules et fragments inédits, vyd. L. Couturat $(=C)$, Paris 1903, str. 13 n., § 7. Tělesům by tak mimo vjemy jednotlivých monád nepř́íslušela žádná skutečná existence, tj. byla by pouhými fenomény. Srv. N. Fenton, A New Interpretation of Leibniz's Philosophy, str. 234. Rovněž J. V. Buroker je přesvědčen, že ,,jelikož existují výhradně jednoduché substance..., zmatené percepce jednoduše transformují agregáty monád ve fyzikální objekty.“ Kdyby totiž existovaly rovněž substance složené, nebylo by už takové transformace zapotřebí. Viz J. V. Buroker, Space and Incongruence. The Origin of Kant's Idealism, Dodrecht 1981, str. 67.

2 Pozdními spisy jsou v kontextu této studie míněny ty, jejichž datace spadá do let $1712-1716$.

3 To přesvědčivě dokazuje G. Hartz, Leibniz's Final System. Monads, Matter and Animals, London 2007. Průkopnickým textem ohledně Leibnizovy teorie 
budiž fakt, že, nahlédneme-li např́ḱlad do korespondence s Antoinem Arnauldem (1686-1690), překvapivě se dozvídáme, že zde Leibnizovi za příklad substance vůbec nesloužila monáda, nýbrž právě tzv. složená substance. Je to pochopitelné, nebot' monády si tehdy musely počkat ještě dalších deset let, než je Leibniz do své filosofie zavedl. ${ }^{4}$

V rámci předkládaného textu se tedy pokusíme prokázat dvojí tvrzení:

a) Historicky starší obdoby Leibnizova pojmu monáda (substanciální forma, entelechie, duše), a občas dokonce ani konkrétní výskyty samotného pojmu monáda, mnohdy nelze považovat za prostou variaci téhož pojmu, nebot' se na rozdíl od pozdějších čistě duchovních monád nejednalo o substance jednoduché, nýbrž o substance složené, případně o pouhé nedílné součásti složených substancí. ${ }^{5}$

b) Nauku o složených substancích Leibniz ve skutečnosti nikdy neopustil.

\section{Složené substance}

Jak je patrné z Leibnizova kategorizačního schématu zaslaného př́lohou k dopisu belgickému theologovi Des Bossesovi, monády rozhodně nebyly jediným typem substance, s nímž Leibniz pracoval. ${ }^{6}$ Důvodem, proč Leibniz zvažoval i jiný typ substancí, je fakt, že monády samotné podle něho nemohou zakládat kompletní složenou substanci, samy o sobě totiž neutvářjí žádnou skutečnou jednotu, nýbrž pouze jednotu ve smyslu agregátu. ${ }^{7}$ Právě proto je nezbytné, aby existoval ještě prostřední stav

složených substancí byl však již text Roberta Adamse (R. M. Adams, Phemomenalism and Corporeal Substance in Leibniz, in: Midwest Studies in Philosophy, 8, 1983, str. 217-257).

4 G. Hartz, Leibniz's Final System, str. 83.

5 Tamt., str. 163.

6 G. W. Leibniz, Leibniz an des Bosses [19 August. 1715], in: GP II, str. 506.

7 Jak píše G. Hartz, Leibniz ,ve skutečnosti nikdy nezamýšlel ponechat monády ,na poličce‘, aby tak vlastním zpo̊sobem vnímaly a usilovaly napříč samotářskou věčností“", čímž autor poukazuje na solipsistické důsledky čistě idealistických interpretací. Bez existence složených substancí by totiž nedocházelo k žádné skutečné interakci, takže by si žádná monáda ve své izolaci nemohla být jistá, zda na světě kromě ní a pouhých fenoménů existují ještě i další monády. Viz G. Hartz, Leibniz's Final System, str. 133. To, že vyjma entit, jež Leibniz nazýval monádami, musí existovat ještě jiné, rovněž substanciální entity, ostatně dle Leibnizových vlastních slov obecně uznávali už peripatetikové: „Peripatetikové vesměs uznávali cosi substanciálního kromě monád, jinak by vposledku žádné substance kromě monád 
vedle substance a pouhé její modifikace, ve smyslu neoddělitelného bližšího určení substance, totiž substancializovaná jednota per se neboli právě substance složená (nazývaná Leibnizem též tělesná substance, stroj či přímo živočich). ${ }^{8}$

Z tohoto hlediska je klíčová právě Leibnizova korespondence s Des Bossesem, v rámci níž je zdůrazněno, že tělesné substance jsou uchopitelné výhradně tehdy, pokud uznáme skutečnou jednotu mezi monádami v podobě určitého substanciálního pouta (vinculum substantiale), ${ }^{9}$ tj. pojítka schopného učinit z pouhého souboru monád skutečnou jednotu, skutečné těleso. ${ }^{10}$ Existenci těles totiž podle Leibnize nelze uchopit na základě pouhého principu harmonie, je-li tato harmonie pojímána coby předzjednaná, takže nijak nevyrůstá ze vzájemného vlivu monád. Vždyt' stejným způsobem by spolu jednotlivé monády mohly harmonizovat i v př́ipadě, že by se jednalo o pouhý agregát. Kdyby měly existovat výhradně duše či monády, předzjednaná harmonie by jistě byla dostačující, v takovém př́ípadě by však vymizela veškerá skutečná rozprostraněnost a samozřejmě také skutečný pohyb.$^{11}$ Předzjednaná harmonie je zkrátka sama o sobě nedostačující proto, že nevysvětluje existenci skutečných těles, nýbrž pouze monád a fenoménů.

Podle Leibnize scholastikové přisuzovali obdobně sjednocující funkci akcidentům, nebot' ty pro ně rovněž nebyly pouhými modifikacemi substance, ve smyslu od ní neoddělitelných určení, ale samozřejmě ani zdrojem modifikací, tj. substancí samou. ${ }^{12}$ Akcidenty se totiž, na rozdíl od modů, sice v substanci nacházejí přirozeně, nikoli však bytostně,

neexistovaly.“ G. W. Leibniz, Leibniz an des Bosses [26 Maji 1712], str. 444. Jak totiž potvrzuje také D. Heider ohledně Suáreze, ,jsoucnem per se ... zdaleka nemusí být jen zcela jednoduchá jsoucna (jako je tomu v př́ípadě Leibnizových monád), ale i jsoucna složená.“ D. Heider, Suárez a jeho metafyzika. Od pojmu jsoucna přes transcendentální jednotu $k$ druhuim transcendentální jednoty, Praha 2010, str. 212.

8 G. W. Leibniz, Leibniz an des Bosses [20 Sept. 1712], in: GP II, str. 459.

9 Tamt.

10 Viz D. Rutherford, Metaphysics: The Late Period, in: N. Jolley (vyd.), The Cambridge Companion to Leibniz, Cambridge 1995, str. 162. První zmínka o vinculum substantiale se ovšem objevuje teprve in: G. W. Leibniz, Leibniz an des Bosses [Januar. 1710], in: GP II, str. 399.

11 G. W. Leibniz, Leibniz an des Bosses [26 Maji 1712], str. 444. Srv. týž, Leibniz. an des Bosses [5 Febr. 1712], in: GP II, str. 436 a týž, Leibniz an des Bosses [16 Junii 1712], in: GP II, str. 451.

12 Viz C. Noreña, Suarez and Spinoza. The Metaphysics of Modal Being, in: Cuadernost salmantinos de Filosofia, 12, 1985, str. 163-182. 
takže zásahem absolutní síly Boží je jim umožněno existovat i bez př́íslušného subjektu..$^{13} \mathrm{O}$ skutečné, tj. neoddělitelné substanciální jednotě tudíž nemůže být řeč, a přesto tu scholastikové byli ochotni o jednotě hovořit. Bytí a jednota pro ně zkrátka představovaly natolik konvertibilní pojmy, že za určitých okolností prrisuzovali skutečnou jednotu dokonce i jednotkám akcidentálním, například počtu či, obecně vzato, agregátům. Tatáž kritéria, tj. kritéria jednoty navzdory oddělitelnosti, však podle Leibnize splňuje i jeho substanciální řetězec, který podle něho také spočívá v substanci samé, nikoli však jako akcident, nýbrž jako to, co scholastikové nazývali substanciální formou. Leibniz tak poznamenává: „Avšak nijak nevidím, jak by to [co tvrdí scholastikové] bylo možno vysvětlit, liší-li se to od mého substanciálního řetězce, jenž vskutku spočívá v subjektu, přece však nikoliv coby akcident, nýbrž coby scholastická substanciální forma čili coby pramen modifikací..."14

Akcidenty samotné, mezi něž spadá i jednota mezi monádami, totiž Leibniz na rozdíl od scholastiků považoval za pouhé modifikace. Vede ho k tomu náhled, že pokud chceme odlišit to, co je abstraktní (to, co spočívá v subjektu), od toho, co je konkrétní (od subjektu samého), a odpovědět na otázku, co znamená být v subjektu či být v něm zahrnut, musíme zahrnutost chápat jako modus či stav subjektu. Tato zahrnutost pak může být bud esenciální - takže změna subjektu vyvolává změnu povahy celé substance -, nebo akcidentální, kdy je nazývána modifikací, jež může libovolně vznikat a zanikat, aniž by tím povaha subjektu byla dotčena. ${ }^{15}$ Oproti tomu Leibnizova vlastní složená substance, jež je utvářena monadickým poutem, podle něj vskutku není ani pouhou jejich modifikací, ani jim nepřináleží coby substancím - tatáž modifikace totiž nemůže náležet několika subjektům současně -, nýbrž sama je substancí. Přestože je tedy substance tohoto typu skutečně závislá na příslušných

13 „Takové akcidenty, o nichž tvrdili, že přirozeně spočívají v subjektu, přesto scholastikové nepojímali esenciálně, nebot' na základě absolutní schopnosti Boží by mohly existovat i bez subjektu." G. W. Leibniz, Leibniz an des Bosses [19 August. 1715], in: GP II, str. 504. Pokud není uvedeno jinak, veškeré překlady jsou naše vlastní.

14 Týž, Leibniz an des Bosses [19 August. 1715], str. 504.

15 „Ani mi není jasné, jak bychom mohli odlišit abstraktní od konkrétního čili od subjektu, v němž spočívá, nebo jak srozumitelně vysvětlit, co to vlastně znamená spočívat či být zahrnut v subjektu, bez toho, že bychom uvažovali zahrnutost coby modus čili stav subjektu, jenž je bud' esenciální, takže jej nelze změnit jinak než změnou povahy jeho substance, od níž se také ve skutečnosti v žádném ohledu neliší, anebo je akcidentální, takže je nazýván modifikací, jež nastává i ustává při zachování subjektu.“ Týž, Leibniz an des Bosses [20 Sept. 1712], str. 458. 
monádách, nejedná se o závislost logickou v tom smyslu, že by od nich nemohla být oddělena dokonce ani nadpřirozeným zásahem Božím, nýbrž o závislost čistě přirozenou, kdy monády přirozeně usilují o sjednocení v podobě složené substance, $\mathrm{k}$ čemuž dochází, pokud Bůh nerozhodne jinak. ${ }^{16}$ Ten pak může rozhodnout o využití konkrétní složené substance (např́klad kamene) pro sjednocení jiných monád, takže tatáž přetrvávající složená substance přestává sjednocovat původní monády (změní se složení kamene při zachování složené substance). Složenou monádu pak může dokonce zcela odstranit a propojením jiných monád ji případně opět nahradit jinou, a to bud’ zrušením jednoty jiných monád a přesunem této jednoty na místo oné odstraněné složené substance (změní se složená substance při zachování původního složení), či při zachování původních, přirozeně sjednocených monád, k nimž nadpřirozeným způsobem přidává další ${ }^{17}$ Řečeno zkrátka, Bůh může nadpřirozeně působit i proti přirozené tendenci jednotlivých monád sjednocovat se konkrétním způsobem (např́íklad do podoby kamene), takže se z nich opět stává pouhý agregát, jenž už není tělesem. Původní těleso samotné (kámen) však přesto může být zachováno a pouze „přesunuto“, takže se ve výsledku změní jen jeho složení (bude se jednat o totožné těleso, sestávající však z jiných monád, než z jakých bylo složeno původně).

Je zřejmé, jaké záměry zde Leibniz sleduje: jedná se o originální pokus vysvětlit proces transsubstanciace při eucharistii, kdy Bůh spolu s odstraněním substanciálního řetězce chleba a vína ruší současně také veškeré jejich dosavadní akcidenty, takže se z nich opět stávají pouhé agregáty náchylné ke sjednocení jiným řetězcem, tentokrát Kristovým tělem a krví. Monády, z nichž byly obě entity původně složeny, však touto změnou zůstávají nedotčeny, a to dokonce i z hlediska „fenomenálního“ (jeví se stejně bez substanciálního řetězce i s ním). Řečeno s Leibnizem:

16 „Na monádách [tato substance] nezávisí na základě závislosti logické (zajisté ne tak, že by od nich nemohla být oddělena ani nadpřirozeně), nýbrž toliko přirozeně čili aby složenou substanci nepřestávala sjednocovat, pakliže by Bůh nezamýšlel jinak..." Týž, Leibniz an des Bosses [20 Sept. 1712], str. 458.

17 „Bůh může tutéž [jednotu] připojit k jiným monádám, aby tak přestala sjednocovat předchozí. Může ji rovněž prostě odstranit a nahradit ji jinou při sjednocení jiných monád, a to bud' tak, že by přestala sjednocovat jiné a byla přenesena z jedněch monád na druhé, nebo tak, že by si zachovala své monády, jež přirozeně sjednocuje, nyní by však vskutku nadpřirozeně sjednocovala rovněž nové.“ G. W. Leibniz, Leibniz an des Bosses [20 Sept. 1712], str. 458. Viz také týž, Leibniz. an des Bosses [Januar. 1710], str. 399. 
„Substanciální řetězce monád Kristova těla budou přesunuty do substanciálních řetězců monád našich těl, jež by v nich jinak disponovaly substanciálními pouty monád chleba a vína. A tak námi bude zakoušena substance Kristova těla a krve. Vždyt' substanciální řetězce oněch monád budou zrušeny, a po odeznění fenoménů chleba a vína čili po zničení druhů budou muset být obnoveny zajisté nikoliv takové, jakými byly předtím, nýbrž takové, jakými se nově staly, pakliže fakticky nebylo zničeno nic.“"18

Uskutečněná změna tudíž nebude nijak pozorovatelná. Jakmile se však veškeré původní monády po pozření opět rozloží, bude se již jednat o rozložené substance Kristova těla, nikoliv chleba a vína. Právě tato logická nezávislost substanciálního řetězce na příslušných monádách tudíž vysvětluje, jak si mohou být dokonce i tak zásadně odlišné substance, jakými jsou Kristovo tělo a krev na jedné straně a chléb a víno na straně druhé, k nerozeznání podobné. Leibniz však doplňuje ještě následující tvrzení, sugerující, že by mohly existovat pouze monády:

„Měl bych tedy raději tvrdit, že mimo monády zajisté nezůstávají žádné substance, nýbrž druhy, ty to že však přesto nejsou ilusorní, jako je tomu $\mathrm{v}$ př́ípadě snu, meče ukazujícího na nás z konkávního zrcadla, či doktora Fausta konzumujícího vavřínový věnec, nýbrž že se jedná o skutečné fenomény, jakým je např́iklad duha či parhelium nebo jakými jsou podle karteziánů, ale také fakticky, jednotlivé barvy." ${ }^{\text {"19 }}$

Jak se zdá, Leibniz se tedy pokusil existenci složených substancí vyvrátit. Složená bytí, jež nejsou jednotou o sobě, čili nejsou držena pohromadě substanciálním řetězcem či takříkajíc jedním duchem, jsou totiž podle něj vskutku pouhými semi-entitami, tj. agregáty neboli, jak je opět patrné ze zmíněného schématu, fenomény. ${ }^{20}$ Semi-entitami jednoduchých substancí jsou např́íklad armáda či hromada kamenů, semi-akcidenty jsou např́íklad barvy, vůně nebo chuti. Pokud by tedy existovaly pouze monády bez substanciálního pouta, všechny tyto agregáty by vskutku byly pouhými fenomény, třebaže skutečnými. Je však třeba upozornit, že pro složenou, substanciálním řetězcem obdařenou substanci je - jak zní Leibnizovo definitivní stanovisko formulované v právě citovaném

\footnotetext{
18 Týž, Leibniz an des Bosses [19 August. 1715], str. 505.

19 Tamt., str. 504.

20 Viz tamt., str. 506.
} 
dopise - disponování konkrétními monádami samo o sobě přirozené, třebaže nikoliv bytostně, nýbrž pouze nahodile:

„Tělesná substance je něčím reálným mimo monády, podobně jako je čára něčím ustanoveným mimo body... Kdyby tento substanciální řetězec monád neexistoval, veškerá tělesa i se svými kvalitami by nebyla ničím než opodstatněnými fenomény, podobně jako duha či odraz v zrcadle.“"21

Složené substance tudíž existovat musí, nebot' svět by byl bez nich pouhým fenoménem, třebaže opodstatněným.

\section{2. Živočichové}

Nelze vyloučit, že Leibnizovo tvrzení, podle něhož agregát není substancí, nýbrž substancemi ${ }^{22}$ bylo míněno tak, že pokud má nějaká entita být plnohodnotným, tj. dostatečně sjednoceným agregátem, musí, na rozdíl od (jednoduchých) substancí, které existují samozřejmě, splnit určité nezbytné podmínky. ${ }^{23}$ Tyto podmínky jsou s jistotou splněny u složených substancí nazývaných živé těleso či živočich (animal): ${ }^{24}$ uspořádanost agregátu je tu dána přítomností dominantní substance, jež vykazuje zřetelné percepce. ${ }^{25}$ Nevědomé monády tedy dávají vzniknout agregátu bud’

21 Tamt., str. 504.

22 „Tělesa, jež jsou lidově považována za substance, nejsou ničím než reálnými fenomény, jež nejsou o nic více substancemi než parhelia či duhy... Jedině monáda je substancí, těleso substancí není...“ Týž, Leibniz an de Volder [21 Januar. 1704], in: GP II, str. 261 n. „Sekundární látka čili masa není substancí, nýbrž substancemi: nikoliv tedy stádo, nýbrž živočich; nikoliv rybník, nýbrž ryba je substancí." Týž, Leibniz an Joh. Bernoulli, in: týž, Leibnizens Mathematische Schriften, vyd. B. Gerhardt, I-VII (= GM), Halle 1859, III, str. 537. „Rozprostraněné čili látka není substancí, nýbrž substancemi.“ Týž, Leibniz an de Volder [23 Junii 1699], in: GP II, str. 183. „Látka ... není substancí, nýbrž substancemi jako stádo ovcí a rybník plný ryb. Za tělesné substance považuji pouze přirozené stroje obdařené dušemi nebo něčím analogickým; v opačném př́ípadě nebude existovat skutečná jednota.“ Týž, Leibniz an Jaquelot [22 Mars 1703], in: GP III, str. 457 n., § 1.

23 Viz G. Hartz, Leibniz's Final System, str. 103.

24 Viz tamt., str. 160.

25 Viz G. W. Leibniz, Principes de la nature et de la grâce fondés en raison, in: GP VI, str. 599, § 4. 
neuspořádanému, nebo takovému, jehož centrum neutvářejí. ${ }^{26}$ Oproti tomu každá stvořená jednoduchá substance, vykazující zřetelné percepce, je centrem substance složené (jíž je právě živočich), tvořené nekonečnou masou jiných, tělesných monád, a je v tomto smyslu principem jejich jednoty. Jak Leibniz poznamenává: „Vskutku by duše celku nebyla ničím než duší každičké soukromě oduševnělé části, kdyby ovšem sama v celém živočichovi nedominovala na základě struktury celku." ${ }^{27}$ V člověku (tj. v živočichu) se pak nachází skutečná jednota korespondující s tím, co v nás bývá označováno jako „jä“. Taková jednota by se však nemohla vyskytnout $\mathrm{v}$ umělých strojích ani v jednoduché mase či hmotě ${ }^{28}$ takže veškeré stroje, jež jsou vytvořeny uměle, co do své komplexnosti v porovnání se stroji živými naprosto zaostávají. ${ }^{29}$ I organické tělo je pak sice, stejně jako jakákoliv jiná masa, pouhým agregátem živočichů či jiných živoucích, a tedy organických bytostí či malých předmětů nebo mas, i ty jsou však zpětně analyzovatelné na další, tentokrát už vskutku elementární živoucí bytosti, sestávající z primitivního prvku organického těla a z duše. ${ }^{30}$

Živočichové jsou tedy definováni výhradně na základě svého složení: naprosto každý živočich sestává z dominantní monády a několika dalších monád (tvořících jeho organické tělo, zvané též organický či přirozený stroj, druhotná látka či prostě hmota). ${ }^{31} \mathrm{~V}$ živočichovi se tak musí nacházet jak forma, respektive duše, jež opakovaně sloužila za př́klad formy

26 Srv. J. Moreau, Svět Leibnizova myšlení, přel. M. Pokorný, Praha 2000, str. 162 .

27 G. W. Leibniz, Leibniz an de Volder, in: GP II, str. 194; srv. týž, Principles de la nature et de la grâce fondés en raison, in: GP VI, str. 598 n., § 3 .

28 Viz týž, Système nouveau, in: GP IV, str. 482, § 11.

29 Viz týž, Principes de la nature et de la grâce fondés en raison, str. 598 n., § 3; týž, Système nouveau, in: GP IV, str. 481.

30 Srv. týž, Conséquences métaphysiques, in: $C$, str. 13 n., § 7. Elementární jednotkou je zkrátka výhradně substance - bez ohledu na to, zda jednoduchá, či složená. Na otázku, jaké konkrétní entity do př́íslušné kategorie živočichů spadají, však Leibniz jednoznačnou odpověd’ nenabízí: „Kdybych byl dotázán, co tvrdím konkrétně o slunci, zeměkouli, zemi, měsíci, stromech a podobných tělesech, a také i o zvířatech, nemohl bych absolutně potvrdit, zda jsou oduševnělá či zda jsou alespoň složenými substancemi, nebo zda jsou jednoduše stroji či agregáty vícera substancí. Jediným, co však alespoň mohu prohlásit, je, že pokud žádné tělesné substance, jaké [pro svou argumentaci] potřebuji, neexistují, vyplývá z toho, že tělesa budou pouhými fenomény, podobně jako duha.“ Týž, Leibniz an Arnauld [28 Novembr. / 8 Decembr. 1686], in: GP II, str. 77.

31 Viz G. Hartz, Leibniz’s Final System, str. 160. 
už Aristotelovi, ${ }^{32}$ a posléze rovněž Leibnizovi, ${ }^{33}$ tak látka, nebot' jedna bez druhé by nemohla utvářet kompletní substanci. ${ }^{34}$

Tomuto předpokladu pak odpovídá Leibnizovo tvrzení, že právě živočich, a nikoliv duchovní monáda sama, je tím, co se v daném tělese zachovává navzdory veškerým proměnám, včetně úmrtí. ${ }^{35} \mathrm{~V}$ opačném případě, kdyby se živočich mohl stát dočasně nekompletním, by totiž došlo k porušení principu kontinuity, jenž požaduje vyloučit mimo jiné i takové skoky, jako je absolutní počátek a konec života monády či její absolutní odtržení od těla. ${ }^{36}$ Ostatně právě z těchto důvodů Leibniz zformuloval teorii posmrtné transformace těles, tj. zachování jejich základní struktury, kdy si každá monáda uchovává alespoň infinitesimální část prř́slušného těla, a odmítl teorii převtělování. Základní organizační struktura zkrátka musí zůstat zachována navzdory veškerým změnám. ${ }^{37}$

Dodejme ještě, že živočichové dokáží monádám konkurovat také co do své jednoduchosti. Nebot' zatímco monáda je za jednoduchou substanci označena proto, že neobsahuje žádné reálně odlišné části ${ }^{38}$ živočich - třebaže na základě toho, co bylo dosud uvedeno, jej

32 Viz např. Aristotelés, De an. II,1,412b,11-19; II,4,415b,12-15; Met. VII,10,1035b,14.

33 Také Leibniz totiž za příklady „substanciální formy starých myslitelů“ uvádí „entelechii čili primitivní aktivní sílu, jež je u živočichů duší a u člověka duchem.“ G. W. Leibniz, Leibniz an Jaquelot [22 Mars 1703], in: GP III, str. 457 n., § 8. Nazýval ji rovněž „formálním atomem“, viz týž, Lettres à Fardella [3-13 Sept. 1896], in: týž, Nouvelles lettres et opuscules inédits de Leibniz, vyd. A. Foucher de Careil, Paris 1857, str. 326. Viz také týž, Système nouveau, str. 478 n., § 3; týž, [text bez názvu], in: GP IV, str. 395.

34 Viz týž, Leibniz an Jaquelot [22 Mars 1703], in: GP III, str. 457 n., § 1.8.

35 Viz týž, Système nouveau, str. 481, §9 n.; týž, Considérations sur la doctrine d'un Esprit Universel Unique, in: GP VI, str. 533 a 535.

36 „Nic se neděje náhle, což je jednou z nejlépe potvrzených zásad, totiž že př́íroda nikdy nečiní mezery neboli princip kontinuity." Týž, Nouveaux essais sur l'entendement humain, in: GP V, str. 49. Poprvé sice Leibniz tento princip definoval až v Nouvelles de la rèpublique des lettres z roku 1687, jeho střípky se ovšem nacházejí už v dřívějších spisech, viz týž, Leibniz an Arnauld, in: GP I, str. 72; týž, Theoria motus abstracti, in: GP IV, str. 229, $\$ 7$. Z pozdějších zmínek uved’me namátkou např. týž, Lettre de M. L. sur un principe général utile à l'explication des loix da la nature, in: GP III, str. 52; srv. též GM VI, str. 129.

37 Viz D. Anapolitanos, Leibniz. Representation, Continuity, and the Spatiotemporal, Dodrecht 1999, str. 67. Viz. např. G. W. Leibniz, Système nouveau, str. 481, § 9 n.

38 Viz např. první odstavec Monadologie: „Monáda, o níž zde bude řeč, není ničím jiným než jednoduchou substancí, jež vstupuje do složených těles - jednoduchou, tj. bez částí.“ G. W. Leibniz, Monadologie, in: GP VI, str. 607, § 1 (česky in: 
za jednoduchého označit nelze - byl podle Leibnize učiněn jednoduchým prostřednictvím zázraku Božího. ${ }^{39}$ Můžeme tedy odmítnout tvrzení D. Rutherforda, podle něhož Leibniz jednotu těla a duše ve skutečnosti nikdy explicitně neprohlásil za náboženské tajemství, ${ }^{40} \mathrm{i}$ tvrzení G. Hartze, podle nějž jsou zde ti, jimž se zázraky v metafyzice nezamlouvají, na správné adrese, nebot' Leibniz je také odmítal. ${ }^{41}$ Proti uvedeným tvrzením lze namítnout, že Leibniz explicitně označil za tajemství (arcanum) nejen jednotu těla a duše, ale především také nesmrtelnost živočichů, tedy přetrvávání těchto složených substancí i po smrti. Nebot' přesto, že na ni lze usuzovat na základě pravidelnosti pozorovatelných tělesných transformací, nikdy ji nelze prokázat s definitivní platností. ${ }^{42}$

Živočichové tak mohou plnohodnotně plnit funkci jednoduchých substancí, nebot' se rovněž jedná o elementární jednotky nepodléhající dělení: jejich složenost zkrátka nijak neohrožuje jejich jednoduchost. ${ }^{43}$ Jedná se však o komplexnější typ složení, zahrnující nejen složení monadické, tj. složení z primární látky a entelechie, ale také složení organického stroje a další složení tohoto stroje se speciální monádou. Jak upozorňuje Leibniz:

„V monádě čili kompletní jednoduché substanci nepřipojuji k entelechii nic než primitivní pasivní sílu, vztaženou k mase celého

týž, Monadologie a jiné práce, překl. J. Husák, Praha 1982, str. 156). V monádách totiž nelze narazit na nic než percepce a jejich změny, tamt., str. 609, § 17. Viz také týž, Conséquences métaphysiques, 13 n., § 7; a týž, Système nouveau, str. 482, § 11 či týž, Principes de la nature et de la grâce fondés en raison, str. 598, § 1. Podobně lakonicky se přitom Leibniz v souvislosti s jednoduchostí monád vyjadřoval už ve své rané fázi, kdy jednoduché prvky označil za neanalyzovatelné a nedefinovatelné (viz týž, Quod ens perfectissimum sit possibile, in: Sämtliche Schriften und Briefe, Darmstadt 1923-2013 (= A), VI, 3, str. 572, § 5, pozn. 8), s tím, že ohledně jednoduchosti forem není co dodat (viz týž, De formis seu attributis Dei, in: A VI, 3 , str. 514, § 11). Obvykle Leibniz ztotožňoval jednoduchost s neurčeností, přičemž o určenosti se vyjadřoval v souvislosti s útvarem a jeho hranicemi. Z geometrického hlediska se tedy jednoduchost projevuje absencí vnitřních hranic, což skutečně indikuje absenci částí (viz V. de Risi, Geometry and Monadology. Leibniz's Analysis Situs and Philosophy of Space, Berlin 2007, str. 178).

39 G. W. Leibniz, Principia logico-metaphysica, in: A VI, 4B, str. 1649, § 1-5.

40 D. Rutherford, Metaphysics: The Late Period, str. 158.

41 „Ti, kteří nejsou spokojeni s mystériem v jádru své metafyziky, jsou na správné adrese: Leibniz je rovněž neměl rád.“ G. Hartz, Leibniz’s Final System, str. 129.

42 G. W. Leibniz, [text bez názvu], in: GP VII, str. 199.

43 G. Hartz, Leibniz's Final System, str. 191. 
organického těla, jejíž část zajisté neutvářejí zbylé podřízené monády, umístěné do orgánů, třebaže jsou jí bezprostředně vyžadovány, a spolu s prvotní monádou se sbíhají do organické tělesné substance čili živočicha a rostliny. Rozlišuji tedy: 1) primitivní entelechii neboli duši; 2) látku, ovšem primární, čili primitivní pasivní sílu; 3) kompletní monádu z těchto dvou; 4) hmotu neboli sekundární látku čili organický stroj, k němuž př́isluší nespočet podřízených monád a 5) živočicha či tělesnou substanci sjednocenou dominantní monádou do podoby stroje." ${ }^{* 44}$

Složené substance tedy sestávají z nespočtu monád, z nichž každá se ještě dále rozkládá na prvotní látku a duši. Jim nadřazená složená substance pak představuje souhrn takovýchto monád zvaný organické tělo obohacený o jednu monádu se speciálním významem, tj. monádu dominantní, jež ve složené substanci plní stejnou funkci jako duše v monádě. V dopise Bernoullimu z roku 1698 Leibniz dokonce poznamenává, že kompletní monádou neboli individuální substancí není ani tak duše samotná, jako spíše živočich či něco jemu analogického, obdařeného duší či formou a organickým tělem. ${ }^{45}$

To, že Leibniz v citovaném dopise považuje za složené dokonce i monády samotné, by nás tváří v tváŕ tolika překvapivým zjištěním nemělo nijak vyvést z míry. Dokonce i monády totiž podle Leibnize disponují vzájemně rozlišitelnými prvky, třebaže se v jejich případě jedná o prvky rozlišitelné výhradně pojmově. Přesněji řečeno, Leibniz uvádí, že naprosto vše, co bud' existuje, nebo je alespoň myslitelné, je složeno z částí, at' už skutečných, či alespoň pojmových. ${ }^{46}$ Monády přitom stále označoval za jednoduché, tj. za entity skutečnými částmi nedisponující, přičemž jedinými částmi, jaké tedy lze u monád uvažovat, jsou části rozlišitelné pojmově..$^{47}$

44 G. W. Leibniz, Leibniz an de Volder [20 Junii 1703], in: GP II, str. 252.

45 „Kompletní monádou čili jednotlivou substancí nenazývám ani tak duši, jako spíše samotného živočicha či něco analogického, obdařeného duší či formou a organickým tělem.“ Týž, Leibniz an Bernoulli [20 Septemb. 1698], in: GM III, str. 542, § 4. Viz také týž, De ipsa natura, in: GP IV, str. 511.

46 Viz týž, Dissertatio de Arte combinatoria, in: $G M$ V, str. 21, § 10.

47 Na základě uvedené textové evidence ovšem není zřejmé, zda nebyly pojmové části vyhrazeny pouze entitám myslitelným, a tedy nikoliv reálným, jimiž monády bezpochyby jsou. K tomu uved’me, že v pozdních textech Leibniz zavedl exaktní definici části jakožto ingredience co do své povahy homogenní s jednotkou, která ji zahrnuje. Jsou-li ovšem části definovány takto, pak monády nelze považovat 
V souladu s uvedeným tak Leibnizovi ještě během jeho vrcholného období sloužily za příklad substance spíše aristotelské složeniny z látky a formy, a ještě poté, co zavedl kategorii monády, jí přisuzoval dva odlišitelné aspekty, totiž, jak je patrné z poslední uvedené citace, primitivní entelechii či duši a primární či primitivní pasivní látku. ${ }^{48}$ Kompletní monáda je tedy tvořena oběma komponenty, třebaže jsou, podobně jako v případě Aristotelova hylemorfismu, reálně neoddělitelné..$^{49}$ Leibniz tak pojímal povahu monád hylemorficky zřejmě proto, že jim náležely mnohé funkce, jež byly dříve přisuzovány scholastickým substanciálním formám (např́íklad funkce individuační)..$^{50}$

Důkazem, že zde máme co do činění s definitivním stanoviskem, budiž tvrzení z pátého dopisu Samuelu Clarkovi z roku 1705, kde Leibniz uvádí:

„Nebudu zde rozvádět svůj názor vysvětlený jinde, že žádné substance zcela zbavené látky neexistují. Souhlasím se starými mysliteli a s tím, co odpovídá rozumu, že andělé či inteligence a duše oddělené od hrubého těla vždy disponují tělem subtilním, třebaže jsou sami netělesní.“51

Tato pasáž tudíž potvrzuje Hartzovo tvrzení, že pro Leibnize jsou nerozprostranění, navzdory svému propojení s látkou, dokonce i živočichové,

za složené z částí. Ostatně doslovné označení podřízených monád či primitivních sil za části př́ílušných monád se u Leibnize nevyskytuje. Analogie týkající se složených substancí naopak naznačuje, že ani monádu Leibniz za dělitelnou na homogenní části nepovažoval. Nebot' i kdyby pouhý nesjednocený agregát substancí vytvářel těleso, přece by podle Leibnize na rozdíl od pouhého fenoménu toto těleso nebylo utvořeno na způsob celku sestaveného z částí, jelikož část je vždy homogenní vzhledem k celku. Kdyby byl však živočich vskutku pojímán coby těleso disponující homogenními částmi, tj. coby těleso dělitelné a zničitelné, nebyl by substancí ani ničím nezničitelným. Totéž platí také o člověku. Vždyt' je-li člověk samotným Já, nemůže být rozdělen ani zemřít, ani není částí homogenní hmoty. Viz G. W. Leibniz, Initia rerum mathematicarum metaphysica, in: GM VII, str. 19; týž, De serie rerum, corporibus et substantiis, et de praedeterminatione, in: A VI, 4B, str. 1671, §§ 1-3 a 12-16.

48 „V monádě čili jednoduché substanci zajisté nedávám do souvislosti s entelechií nic než primitivní pasivní sílu vztaženou k mase celého organického těla..." Týž, Leibniz an de Volder [20 Junii 1703], in: GP II, str. 252.

49 Viz G. Hartz, Leibniz's Final System, str. 190.

50 Viz J. Jorati, Leibniz's Ontology of Force, in: Oxford Studies in Early Modern Philosophy, 8, 2019, str. 189-224.

51 G. W. Leibniz, Leibniz’ fünftes Schreiben, in: GP VII, str. 406, § 61. 
podobně jako jsou navzdory svému hylemorfickému složení nerozprostraněnými rovněž monády, nebot' např́iklad ani anděly navzdory jejich propojení s hmotou za rozprostraněné považovat nelze. ${ }^{52}$ Mezi monádami a živočichy tedy zřejmě neexistuje žádný relevantní rozdíl: obojí je navzdory své složenosti nerozprostraněné. Pokud by se však v případě monád na rozdíl od živočichů jednalo o složenost čistě pojmovou, bylo by stále ještě možné argumentovat, že monády jsou nerozprostraněnými právě pro svou faktickou (tj. nikoliv pojmovou) jednoduchost. To ovšem v případě fakticky složených substancí, jakými jsou živočichové, neplatí. Podle Leibnize nemůže ,,jednoduchá substance ... disponovat rozprostraněností, nebot' veškerá rozprostraněnost je složená.“53

Jak ale vyplývá ze spisu Mira de natura substantiae corporeae (Divy ohledně povahy tělesné substance), kde je nerozprostraněnost výslovně přisouzena tělesným substancím, není tomu tak, že by složené substance, na rozdíl od monád, rozprostraněné být musely. Podle Leibnize totiž „[ani] tělesné substanci nepřináleží rozprostraněnost, ... nýbrž pouze látka čili princip pasivity neboli přirozené omezenosti a forma čili princip aktivity neboli přirozené neomezenosti. “54 Jak správně vypozoroval Hartz, živočichové tedy do agregátů nevnášejí rozprostraněnost o nic více než monády samy ${ }^{55}$ Nejenže tak složené substance dokáží ve všech ohledech konkurovat monádám, můžeme dokonce tvrdit, že je díky své složenosti dokonce překonávají, nebot' oproti nim disponují výhodou, jíž je situovanost, a tudíž i fyzická interakce (jak je opět patrné z výše zmíněného schématu). Upozorněme tedy, že i monády, ačkoli jsou samy o sobě nerozprostraněné a nesituované, disponují jistým typem pozice (situs), avšak právě jen prostřednictvím toho, co je rozprostraněné, tj. toho, čeho části jsou odděleny vzdáleností (nejsou indistantní). Přesněji řečeno, i monáda sice navazuje vztah koexistence s ostatními monádami, ovšem nikoliv sama od sebe, nýbrž právě prostřednictvím př́íslušného stroje, jejž ovládá, tedy prostřednictvím složené substance. ${ }^{56}$ Tato situovanost monád je přitom nutná, nebot' žádná konečná substance nemůže být oddělena od svého tělesa, a nemůže tudíž nezaujímat určitou pozici

\footnotetext{
52 Viz G. Hartz, Leibniz's Final System, str. 191.

53 G. W. Leibniz, Leibniz an Lady Masham [Septembr. 1704], in: GP III, str. 363.

54 Týž, Mira de natura substantiae corporeae, in: A VI, 4, str. 1465, § 21-23.

55 Viz G. Hartz, Leibniz’s Final System, str. 191.

56 Toho si správně všímá B. Russel, A Critical Exposition to the Philosophy of Leibniz, Cambridge 1900, str. 125, § 71.
} 
(zpočátku Leibniz přisuzoval pozici dokonce i pojmům). ${ }^{57} \mathrm{I}$ jednoduché substance tak musí alespoň takto zprostředkovaně disponovat pozicí $v$ rámci toho, co je rozprostraněné, třebaže je nemožné určit tyto pozice přesně jako $\mathrm{v}$ případě nekompletních fenoménů. ${ }^{58}$

Kromě uvedeného mají navíc živočichové před monádami přednost také z hlediska epistemologického, nebot' jsou na rozdíl od monád snadno uchopitelní.$^{59} \mathrm{~V}$ tomto bodě je třeba upozornit, že zatímco ještě roku 1686 Leibniz tvrdil, že pojem sebe samého či jakékoliv jiné individuální substance je nekonečně složitější a obtížněji uchopitelný než technické pojmy typu koule, ${ }^{60}$ o dvanáct let později už toto tvrzení - právě pod vlivem své teorie živočichů - zásadně přehodnotil: „Ptáš se, jak dlouho je zapotřebí pokračovat za účelem nalezení něčeho, co je substancí, a nikoliv substancemi. Odpovídám, že něco takového se nabízí bezprostředně, a dokonce bez dalšího dělení, přičemž každý živočich je takový. “61 Existuje totiž minimálně jeden př́klad živočicha, s nímž je každý z nás obeznámen naprosto bezprostředně či intuitivně, nebot' každý z nás je bezprostředně obeznámen přinejmenším se sebou samým právě coby živočichem.

\section{Závěr}

Leibnizova zralá metafyzika bývá nezřídka považována za metafyziku monád, tj. jednoduchých, nedělitelných jednotek. Toto tvrzení jistě platí: duše živočichů, substanciální formy či entelechie rostlin i jiných menších stvoření, stejně jako lidská mysl, byly pro Leibnize monádami. ${ }^{62}$ Kromě toho je však o Leibnizovi známo, že se tuto svou nauku, nazývanou monadologie, pokusil zkomplikovat prostřednictvím kategorie

57 Viz G. W. Leibniz, Leibniz an de Volder [20 Junii 1703], str. 253; týž, Dissertatio de arte combinatoria, in: GP IV, str. 35; GM V, str. 12, § $6 \mathrm{n}$.

58 „To, co je jednoduché, i kdyby to nedisponovalo rozprostraněností, přesto musí disponovat pozicí v rámci rozprostraněného, třebaže ji nelze přisoudit přesně jako v př́ípadě nekompletních fenoménů." Týž, Leibniz an de Volder [20 Junii 1703], str. 253.

59 Ohledně monád je totiž situace beznadějná: „Ani nijak nelze narazit na nejmenší fenomény. Substanciální jednotky vskutku nejsou částmi, nýbrž podkladem fenoménů.“ Týž, Leibniz an de Volder [30 Junii 1704], in: GP II, str. 268.

60 Viz týž, Leibniz an Arnauld [14 Julliet 1686], in: GP II, str. 48 n.

61 Týž, Leibniz an Bernoulli [20 Septemb. 1698], str. 542, § 5.

62 Viz P. Phemister, Leibniz and the Environment, London 2016, str. 34. 
substanciálního řetězce a teorií složených substancí, jež jsou oním řetězcem utvářeny. Status této teorie ovšem není jednoznačný. Například podle Russella Leibniz nikde netvrdí, že by sám kategorii substanciálního řetězce zastával. Zavedl ji podle něj pouze proto, aby přesvědčil katolické theology, že monadologie je kompatibilní rovněž s jejich vírou. ${ }^{63}$ Leibniz sám totiž podle Russella sice původně uznával ,jistou skutečnou metafyzickou jednotu duše a organického těla, “64 Des Bosses jej však přesvědčil o tom, že tato jednota je pro potřeby katolické ortodoxie nedostačující. Leibniz tedy hypotézu vinculum substantiale zavedl coby pojetí, jež sice osobně nezastává, zato však může být přijatelné pro církev. ${ }^{65}$ Sám ovšem poznamenal, že toto vinculum substantiale je užitečné, pouze ,pokud nás víra vede k tělesným substancím. “66 Mnozí jsou navíc přesvědčeni, že Leibniz teorii složených substancí nejpozději po roce 1703 zamítl. $^{67}$

Avšak důkazů dosvědčujících, že teorie složených substancí Leibnizovi rozhodně nesloužila coby pouhý alibismus, jehož se při nejbližší př́ležitosti neváhal zbavit, je hned několik. Právě teorie složených substancí totiž přinejmenším zčásti vysvětluje, proč Leibniz dokonce ještě i v rámci monadologické etapy popisoval monády hned třemi různými způsoby: jako imateriální substance s percepcemi a žádostivostí, jako síly a jako hylemorfické složeniny sestávající z primární látky a substanciální formy. Za pozornost přitom stojí, že Leibniz občas užíval všech tří pojetí v rámci jediného textu. ${ }^{68}$ Ony imateriální substance totiž sestávají právě z primitivní síly aktivní i pasivní čili ze substanciální formy a primární látky. V rozmezí let 1686-1715, tedy během Leibnizova vrcholného období, se pak zmínka o tělesných substancích vyskytla

63 Viz B. Russell, A Critical Exposition to the Philosophy of Leibniz, str. 152, § 92.

64 „Nepopírám přitom jakousi skutečnou metafyzickou jednotu mezi duší a organickým tělem..." G. W. Leibniz, Leibniz an des Bosses [24 April 1709], in: GP II, str. 371. „Avšak coby přidaná metafyzická jednota není fenoménem..." Týž, Remarque de l'Auteur du Système de l'Harmonie Préetablie, in: GP VI, str. 595.

65 Viz B. Russell, A Critical Exposition to the Philosophy of Leibniz, str. 151, § 92.

66 G. W. Leibniz, Leibniz an des Bosses [5 Febr. 1712], str. 435.

67 Viz G. Hartz, Why Corporeal Substances Keep Popping Up in Leibniz's Later Philosophy, in: BJHP, 6, 1998, str. 193-207, zejm. str. 193; R. Arthur, Infinite Aggregates and Phenomenal Wholes: Leibniz's Theory of Substance as a Solution to the Continuum Problem, in: Leibniz Society Review, 8, 1998, str. 25-45, zde str. 26.

68 Viz J. Jorati, Leibniz's Ontology of Force. Viz také G. W. Leibniz, Système nouveau, str. 478 n.; a týž, De ipsa natura, str. 512, § 12, a týž, Leibniz an Bierling [12 Augusti 1711], in: GP VII, str. 502. 
přinejmenším v šestnácti rozličných textech. ${ }^{69}$ Zatímco v Metafyzickém pojednání jsou ony hylemorfické složeniny zmíněny pouze sedmkrát, v rámci dopisů Arnauldovi už jejich počet vystoupal na rekordních čtyřicet čtyři, přičemž v průběhu Leibnizova vrcholného období se objevily ještě třináctkrát v rámci Nového systému, čtrnáctkrát v dopisech De Volderovi a v Monadologii dokonce třiadvacetkrát. ${ }^{70}$

Ještě v roce 1712 pak Leibniz uvádí, že substance mohou být bud' jednoduché, jako duše, jež nedisponuje částmi, nebo složené, jako živočich, sestávající z duše a organického těla. ${ }^{71}$ Roku 1714 pak zopakoval, že každá monáda spolu s konkrétním tělem dává vzniknout živoucí substanci $^{72}$ a že nejen duše, ale ani živočichové nemohou být stvořeni, ani zaniknout. ${ }^{73}$ Leibnizovi přitom tehdy zbývaly už jen dva roky života. Předpoklad, že by přesto Leibniz ještě mohl konvertovat k čisté monadologii, je přitom zcela neopodstatněný, nebot' dokonce i v pasážích napsaných později se substancialitě složených substancí dostalo nikoliv pouze služebné role ${ }^{74}$ nýbrž byl jim přiznán zcela autonomní status, jako je tomu ostatně i v Monadologii samé. ${ }^{75}$

Připust'me však, že lze nalézt pertinentní textové pasáže, v nichž Leibniz uznává, že vposledku existují výhradně substance jednoduché. ${ }^{76}$ Ostatně v jednom z dopisů De Volderovi se Leibniz nechal slyšet, že $v$ tělesech existují pouze jednoduché substance..$^{77}$ To ovšem nic nemění na tom, že o rok dříve se témuž De Volderovi explicitně zmiňoval o reálné existenci živočichů, jež prritom od jednoduchých substancí

69 Viz G. Hartz, Why Corporeal Substances Keep Popping Up, str. 196.

70 G. Hartz, Leibniz's Final System, str. 156.

71 G. W. Leibniz, Du principe de raison, in: $C$, str. $13, \S 7$.

72 Týž, Principes de la nature et de la grâce fondés en raison, str. 599, § 4.

73 Tamt., str. 601,§6.

74 Tak se u Leibnize ještě roku 1715 dočítáme, že pravá substance (jakou je živočich) se skládá z imateriální duše a organického těla, viz G. W. Leibniz, Leibniz an Remond [4 de Novembre 1715], in: GP III, str. 657, § 3.

75 G. Hartz, Leibniz's Final System, str. 157.

76 G. W. Leibniz, Societas Theophilorum ad celebrandas laudes Dei opponenda gliscenti per orbem Atheismo, in: $C$, str. $14, \S 7$.

77 „V tělesech se nenachází nic než jednoduché substance.“ Týž, Leibniz an de Volder [30 Junii 1704], str. 270. 
striktně odlišoval ${ }^{78} \mathrm{~V}$ rámci jednoho ze svých zřídka citovaných textů ${ }^{79}$ navíc Leibniz provedl myšlenkový experiment spočívající v představě, že zmizí veškerý duch a zachovají se pouze tělesa. Podle Matese by tato představa v kontextu Leibnizovy metafyziky ochuzené o složené substance nebyla vůbec možná, pokud by tělesa byla pouhými fenomény - složené substance tedy Leibniz nutně musel považovat za reálně existující ${ }^{80}$ Leibniz sám přitom upozornil, že pokud by se v člověku fakticky nenacházelo nic než pouhá mysl, nebylo by možné vysvětlit, jak tato vnímá rozrůzněnou skutečnost. ${ }^{81}$ Daniel Garber se navíc správně ptá, jak by se mohl Leibniz zabývat určováním fyzikálních zákonů těles, s nimiž máme běžnou zkušenost, a pokoušet se o založení skutečné fyziky, pokud by, jak se obvykle má za to, byl vskutku idealistou a uznával pouze existenci monád. ${ }^{82}$ Tzuchien Tho přitom upozorňuje - a my tuto domněnku přijímáme -, že Leibnizovi ve skutečnosti nešlo o přísné vymezení elementárních jednotek. Mnohem důležitější pro něj byla otázka po povaze těles samotných. ${ }^{83}$

\section{ZUSAMMENFASSUNG}

In meinem Beitrag untersuche ich die Rolle der zusammengesetzten Substanzen im Allgemeinen und die der Lebewesen im Besonderen im Rahmen des Leibnizschen metaphysischen Systems. Ich versuche zu zeigen, dass die zusammengesetzten Substanzen in der Tat echte und wichtige Konkurrenten der Monaden selbst waren, entweder in Bezug

78 Týž, Leibniz an de Volder [20 Junii 1703], str. 252.

79 Týž, De mente, in: týž, Textes inédits, I-II, vyd. G. Grua, Paris 1948, I, str. 266.

80 G. Hartz, Leibniz's Final System, str. 132.

81 G. W. Leibniz, De origine rerum ex formis, in: De summa rerum, vyd. G. H. R. Parkinson, London 1992, str. 74-77, § 518.

82 D. Garber, Leibniz and the Foundations of Physics, The Middle Years, in: K. Okruhlik (vyd.), The Natural Philosophy of Leibniz, Dodrecht 1985, str. 27 n.

83 T. Tho, What is (not) Leibniz's Ontology, in: Journal of Early Modern Studies, 4, 2015, str. 79-103, str. 92. - Tato studie byla zpracována v rámci řešení projektu Podpora talentovaných studentů doktorského studia na Ostravské univerzitě (ev. č. 00382/2019/RRC) dotačního programu Podpora vědy a výzkumu v Moravskoslezském kraji 2018, řešeném na Filozofické fakultě Ostravské univerzity a projektu SGS03/FF/2019-2020: Bílá místa dějin a současnosti filozofie: Osobnosti a témata na okraji kánonu. 
auf ihre Ausdehnungslosigkeit, ihre Fähigkeit zur physischen Wechselwirkung oder in Bezug auf ihre Einfachheit. Darüber hinaus stellten sie deshalb eine konkurrierende Vorstellung dar, weil die zusammengesetzten Substanzen in gewisser Hinsicht als einfach angesehen werden können; auf der anderen Seite können die Monaden in gewisser Hinsicht als zusammengesetzt betrachtet werden. Allerdings kann damit keine wörtliche Zusammensetzung von Teilen gemeint sein, da Teile als homogen zum Ganze definiert werden. Als ein Beispiel von zusammengesetzten Substanzen untersuche ich die Kategorie der Lebewesen, d.h. zusammengesetzten Substanzen, die mit einer dominanten Monade ausgestattet sind neben einigen untergeordneten Monaden. Typische Beispiele für Lebewesen sind Menschen; allerdings war Leibniz nie im Stande zu entscheiden, was denn sonst zu dieser Kategorie gehören soll. Schließlich zeige ich auf, dass Leibniz tatsächlich nie die Theorie über die zusammengesetzten Substanzen aufgegeben hat: dies war wahrscheinlich nicht nur ein Alibi, um seine Metaphysik in den Augen der Katholiken zu rechtfertigen, wie im Falle von Des Bosses, dem Leibniz mehrere Briefe über die zusammengesetzte Substanz geschickt hat. Deshalb scheint die idealistische Interpretation, die typisch für das Auslegen von Leibniz' spätem Werk ist, nicht im Einklang mit Leibniz' eigenen Intentionen zu sein. Im Gegenteil gibt es eine Reihe von Hinweisen, die darauf hindeuten, dass Leibniz vielmehr an den Körpern selbst interessiert war und nicht nur an der grundlegenden (geistigen) Einheit der Körper.

\section{SUMMARY}

In this paper, I examine the role of compound substances in general, especially animals, in Leibniz's metaphysical system. I attempt to prove that compound substances were indeed significant competitors of monads themselves, be it in terms of their lacking extension, their capability of physical interaction, or their simplicity. In addition, while compound substances may be considered to be simple in some respect, monads in turn may be considered to be composed in some respect. However, this does not mean a literal composition of parts, since parts are defined as homogeneous with the whole. As an example of compound substances, I examine the category of animals, i.e., compound substances endowed with a dominant monad in addition to some subordinated ones. The typical example of animals are human beings; however, Leibniz was unable to decide what else is supposed to belong into this category. Finally, 
I point out that Leibniz, in fact, never abandoned the composite substances theory, and that he did not adopt it merely for alibistic reasons in order to justify his metaphysics in the eyes of the Catholics, as was the case of des Bosses, to whom Leibniz sent several letters about compound substances. Therefore, the idealistic interpretation, a typical one for Leibniz's later work, does not seem to be in accord with Leibniz's own intentions. On the contrary, there are many indications suggesting that he was fairly interested in bodies themselves, not merely in the elementary (spiritual) units of bodies. 